\title{
CHRISTIANITY AND DEVELOPMENT IN THE PACIFIC:
} AN INTRODUCTION

\author{
Philip Fountain ${ }^{1}$ and Geoffrey Troughton ${ }^{2}$
}

\begin{abstract}
Although a significant literature has arisen examining the intersections of Christianity and development in the Pacific, these themes have yet to receive the full attention they deserve. This special issue seeks to encourage further scholarship on these important themes. In this introduction we trace some of the entanglements between religion and development in Pacific history and suggest some productive future research trajectories.
\end{abstract}

Keywords: Pacific; Christianity; development; theology; institutions; materiality

\section{INTRODUCTION}

Christianity and development have a complicated and thoroughly entangled history. Some decades ago the view within mainstream development studies and associated disciplines was that these relationships were either insufficiently interesting or of too limited consequence to warrant much attention. Over the past fifteen years, however, this situation has dramatically changed. As part of a broader 'religious turn' in the study of development, considerable scholarly attention has been devoted to examining the ways in which Christianity has informed development and also how development has reconfigured Christianity (Barnett 2011; Fassin 2011; Feener and Fountain 2018a; Feener and Fountain 2018b; Fountain 2013a; Fountain 2015; Scheer et al. 2018). This special issue on Christianity and development seeks to contribute to this burgeoning scholarly conversation, and to scholarly debates about the role of religion in development more generally, by focusing on the Pacific region. The ubiquity of Christianity in the Pacific and the complex development challenges of the region make it a particularly productive space to explore Christian-development interactions.

A number of distinctive features of the Pacific region make it an especially 
compelling focus for such examination. Perhaps most prominent among these is that the Pacific is famously religious, and specifically Christian. Nearly forty years ago, missiologist Charles Forman $(1982,227)$ declared that this region was 'the most solidly Christian part of the world'. If anything, this statement has become more accurate with the passing of time. By 2010, half of the top twenty Christian nations on earth by percentage of the total population could be found in the Pacific; in each of these nations, reported rates of affiliation to Christianity were at least ninety-seven per cent. ${ }^{3}$ The significance of such affiliation is not merely statistical. As Matt Tomlinson and Debra McDougall $(2012,3)$ have argued, the pervasiveness of Christianity is such that it is 'the ground and starting point for political action' across the region; politics and Christianity are 'inseparable at any level of analysis'. The premise of this special issue is that this is indeed correct for the analysis of development.

Observers and commentators have long been cognisant of the vital roles Christianity plays in Pacific cultures, societies, and economies. Scholars from a range of disciplines - including anthropology, theology, history, and development studies - have noted important interactions between Christianity and development in the region.

In a series of seminal publications that helped launch the anthropology of Christianity as a distinctive field, Joel Robbins $(2003 ; 2004 ; 2007)$ critiqued anthropology's neglect of Christianity, including noting the relative paucity of anthropological studies on Christianity in the Pacific. ${ }^{4}$ This historical neglect no longer holds. There has been a remarkable resurgence of interest in Pacific Christianity among anthropologists. ${ }^{5}$ An expansive vision apparent within this body of work has created space to engage with diverse development concerns, though development has rarely emerged as a primary site of analysis. Similarly, among those that have taken development spaces and objects as central objects of analysis - including, for example, Annelise Riles' sophisticated study of NGOs in Fiji (2000) - religion has been examined only as a secondary concern. ${ }^{6}$

Naturally enough, theologians have been deeply invested in thinking about Pacific Christianity. They have also pioneered critical scholarly engagement with social, political, economic, and ecological concerns. Early theological reflection was carried out under the auspices of missionary agencies and organisations. From the 1970s, innovative studies by Pacific theologians reshaped the field as they sought to imagine culturally Pacific ways of doing Christianity (Forman 2005; Tomlinson forthcoming). A dominant strand within this more recent Pacific theology has addressed issues of contextualisation and indigenisation of Christianity, dovetailing with questions about decolonisation and globalisa- 
tion (Tomlinson, this issue). ${ }^{7}$ Another focus, increasingly prominent in the last fifteen years, has concerned the environment. Combining both indigenous and ecological concerns, Winston Halapua (2010) has argued for 'Theomoana' - an oceanic vision of God - as offering a distinctively Pacific theology. ${ }^{8}$ Organisations such as the Pacific Council of Churches (PCC), formed in 1966, have also been important proponents of Pacific theology, and notable for supporting direct engagement with theologies of development (White, this issue). ${ }^{9}$

There is considerable overlap in the themes that have preoccupied theologians and historians of Pacific Church history. This partly reflects overlap in personnel, and the common institutional bases from which historians and theologians have conducted their work, for example at the Pacific Theological College in Suva, Fiji, and via sponsorship of the PCC and World Council of Churches. Historians of Pacific Christianity have given particular attention to the creation and decolonisation of ecclesial institutions (Taylor and King, this issue). This has resulted in an extensive historiography of missionary activities, the logics of conversion, and the growth of indigenous Christianities. ${ }^{10}$ While some of this scholarship conforms to a version of methodological nationalism, and also methodological denominationalism, a growing number of studies have been attentive to intraregional and transnational networks and flows. ${ }^{11}$

While scholarship from within these three disciplines has pointed to important intersections between Christianity and development in the region, it is striking that none of them has yet furnished a sustained and focused analysis of the topic. The case is even more glaring within the discipline of development studies where there has been remarkably little and limited discussion of religion. The occasional explicit discussion of these themes - and we address some of these below - are exceptions that prove the general rule of avoidance and disinterest. The end result is that a definitive study of the intersections between Christianity and development in the Pacific is yet to be produced. This special issue, with its collated series of provocations, should be read as an extended invitation for the seminal work we hope to see carried out on these themes.

\section{MULTIPLE ENTANGLEMENTS}

The absence of definitive contributions to the analysis of Christianity and development in the Pacific is particularly conspicuous given the remarkable recent surge of interest in 'religion and development. ${ }^{\text {'2 }}$ Emerging literature has highlighted the ways in which religion and development are not two separate spheres which occasionally interact and overlap, but rather are thoroughly entangled, and that these entanglements have significantly shaped our under- 
standings of each.

It is often thought that 'development' emerged only after the Second World War in relation to post-war reconstruction, American imperial expansion, and Cold War competition (Rist 2014). But this genealogy is too short, arbitrarily cutting off longer trajectories. The roots of Western development - its affective, organisational, moral, and political origins - lie in earlier experiments, and as historical scholarship has made clear, these experiments were deeply entwined with Christian missionary and charitable endeavours (Scheer et al. 2018). ${ }^{13}$ These decidedly religious roots continue to shape the ways in which development is practiced. This point is made particularly clearly in Didier Fassin's (2011) seminal analysis of the genealogies of European 'humanitarian reason', in which he argues that Christian theology remains imbued within all manner of humanitarian projects, shaping the logics and ethics via which humanitarian and development activity is undertaken. While humanitarian action continues to evolve and morph, Fassin's argument suggests that an adequate understanding of humanitarianism and development will nevertheless require attention to religious dynamics and to history.

Development can be understood as a modern techno-political form of intervention aimed at activating or enhancing progress toward a desired future (Feener and Scheer 2018; Li 2007; Mitchell 2002). Rather than a singular or static phenomenon deployed in identical ways regardless of context, development is best conceptualised as an amalgam of concepts, practices, ideas, and institutions. It is inherently diverse, contested, and malleable. So, too, is Christianity. In this special issue we have not sought to provide single authoritative definitions of either development or Christianity. Rather, our goal has been to address particular Christianities as they circulate in the Pacific, and different dimensions of development as it appears in a variety of contexts. The forms of Christianity and development addressed in this special issue are by no means exhaustive, but they are nevertheless expansive and, we trust, illuminating of broader dynamics.

In this special issue, our approach to both Christianity and development can therefore be seen as parallel. Avoiding reifying either, we conceptualise both as 'moving targets' (Feener et al. 2015, 243). Christianity and development shift over time and space. Moreover, these reconfigurations take place in dynamic relation with each other (Feener and Fountain 2018b). Neither Christianity nor development as described here originated in the Pacific, but Pacific peoples have made both of them their own, and in the process have translated and renegotiated their meanings and practices. 
The field of religion and development has, over just a short period of time, become a vibrant area of research. Critical and sophisticated studies have been published on the intersections between religion and development addressing different regions of the world. These include studies focused on Africa (Bornstein 2005; Davidson 2016; Fiddian-Qasmiyeh 2014; Freeman 2012; Gifford 2016; Ilo 2011; Scherz 2014; Smith 2008), Asia (Bolotta et al. forthcoming; Bornstein 2012; Feener 2013; Fountain et al. 2015; Huang 2009; Kawanami and Samuel 2013; Rudnyckyj 2010; Scheer et al. 2018; Watanabe 2019; Weller et al. 2017), Latin America and the Caribbean (Hefferan 2007; Hefferan et al. 2009; Occhipinti 2005), and the Middle East (Atia 2013; Benthall and Bellion-Jourdan 2009; Cammett 2014; Gallagher 2007). To date, however, the Pacific has not attracted similar interest. Indeed, the broader field of 'religion and development' has largely by-passed the Pacific region. ${ }^{14}$ There remains much work still to be done to understand the historical entanglements between religion and development in the region. The next section begins to sketch some of the historical dynamics.

\section{PACIFIC CONFLUENCES}

The history of development in the Pacific begins not in the second half of the twentieth century, but rather in the various initiatives of improvement, humanitarian concern, and civilising projects that were undertaken in the nineteenth century. At the forefront of these endeavours were Christian missionaries and mission agencies, though they were by no means the only actors involved. Christian missionaries, including many who came from other parts of the Pacific, were insinuated into the lives, economies, politics, rituals, and kinship networks of communities across the region, with a significantly disrupting effect (Sissons 2014). The array of projects of transformation that were enacted across the Pacific is quite astounding. Church engagements in spiritual, moral, and social transformation spanned diverse fields, including education, literacy, agriculture, and health.

Missionaries, of course, were intent on spreading their faith. Yet evangelisation was always enmeshed - sometimes seamlessly, at other times in fraught tension - with diverse and contested sets of ideas about civilisation, improvement, humanity, affect, race, gender, political ideology, and temporality. Nineteenth century missionaries rarely imagined 'faith' as a privatised and clearly demarcated domain that could be carved off neatly from the host of moral and ethical matters that confronted their converts. Moreover, and more importantly, there is exceedingly little evidence that Pacific converts had any inclination to consider religion as sui generis or clearly differentiated from other similarly 
autonomous domains. Secularism - as a project of instituting differences and policing the boundaries of religion - is best considered as a political project, rather than a social process (van der Veer 2013), and this is a thoroughly recent political innovation in the Pacific. ${ }^{15}$

Missionary projects of intervention rarely unfolded as their designers intended. Instead, unexpected outcomes and cascading effects were the norm. Translation is always a precarious and contingent process (Fountain 2011). This is because European missionaries were never the sole agents involved. Converts could and did reconfigure the faith they embraced, as did those who rejected it as inadequate, immoral, or distasteful. In the process of adopting Christianity, Pacific peoples made it their own, reimagining and remaking it in the process.

The 'missionary era' never really came to an end in the Pacific. On the one hand, there are still plenty of missionaries in and around the Pacific, and from the Pacific to other parts of the world. On the other hand, missionary networks did not so much end as morph into other forms of transnational interconnection and association. Nevertheless, profound changes in the twentieth century had far-reaching effects. The First and Second World Wars reconfigured imperial maps of the Pacific, extending New Zealand, Australia and, briefly, Japan's direct colonial relationships with the islands, ${ }^{16}$ but ending Germany's imperial stint and reshaping British and French colonial regimes. Perhaps most consequentially, the United States greatly expanded its influence, even when it did not assume direct governance roles. Such impacts have been felt through the growing influence of American religious networks, as well as in American development discourses and projects (Morris, this issue). Development rhetoric as it emerged in the United States in the 1940s and 50 s was imagined as a replacement for colonialism with a new system of geopolitical relationships (Rist 2014). And indeed, in the Pacific, discourses of decolonisation and development have historically been deeply interwoven.

Within the waves of decolonisation which reshaped Pacific politics, the churches were often ambivalently positioned (Teaiwa 1994). This ambivalence was hardly new, however. Christian mission had proceeded alongside and via colonial networks, sometimes intimately binding 'cross and flag' though at other times existing together only with great discomfort, if not outright antagonism (Porter 2004; Stanley 1990; Troughton 2017). The movements that led to decolonisation worked to organise against colonial imposition. In recurring patterns across the Pacific, key leaders within these movements cut their political teeth within the Christian churches as pastors, secretaries, preachers, and seminarians (see Clarke, this issue; Taylor and King, this issue; Tomlinson, this issue). 
Decolonisation in the Pacific had a notably Christian hue (Hassall 1990), in which churches played significant roles. This was partly enabled by their prior engagement with parallel processes within the churches themselves, often decades prior to states' achievement of political independence (Gardner 2013). Churches therefore provided patterns and models, as well as gifted and capable individuals, in the decolonisation process (Clarke 2012).

It is better to understand decolonisation as a process rather than an event, and one which remains ongoing (Allen 2018). A series of prominent causes have served as visible flashpoints for renewing movements for a free Pacific. Opposition to nuclear testing in the Pacific by French, British, and American governments brought together diverse actors in a broad movement. Among these, Pacific churches were frequently at the forefront, drawing in other support via their transnational networks (Armstrong 2018; Matheson 2018; Siwatibau and Williams 1982; Teaiwa 1994; Troughton and Fountain 2018; Weir 2012). In so doing, churches established modes of advocacy alongside a growing sense of regional identity and political savvy. Other notable causes that have rallied Pacific churches include the independence movements of Timor Leste and West Papua.

While Pacific churches were working to build movements based on languages of independence and freedom, development economics was simultaneously theorising new forms of dependency. The MIRAв model of development trajectories diagnosed various development challenges besetting small Pacific islands across the region. MIRAB economists perceived four 'locomotives' driving Pacific economies: migration, remittances, aid, and bureaucracy (Bertram 2006). While these elements enabled small Pacific economies to remain relatively strong, they also ensured a high level of vulnerability and precariousness. The MIRAB model occluded discussion of religious networks, including their roles within migration and aid processes.

The mirab model correctly emphasised the growing importance of the Pacific diaspora. Pacific peoples embraced migration opportunities as they opened up in the 1970 and 80 s, and this facilitated the flow of large numbers of migrants traveling within and beyond the Pacific. This led to significant reconfigurations of religious and cultural life, as well as economic opportunity (Pala'amo, this issue; Taylor and King, this issue). But Pacific scholars also critiqued the MIRAB model for its framing of the region. In his seminal paper 'Our Sea of Islands', Epeli Hau'ofa (1993) argued that the Pacific Ocean should not be viewed as creating a set of isolated islands in a vast empty sea, but rather as connecting, linking, and interweaving. Efforts by Hau'ofa and others to imagine a distinc- 
tively 'Pacific Way' involved, as Matt Tomlinson (this issue) argues, theological, developmental, and cultural discourses.

Oceanic themes are not without their own ambiguity, however. The Pacific is often regarded as among the most disaster-prone regions of the world, with high vulnerability to cyclones, tsunami, and other oceanic disasters (McDougall 2016,34-38). The frequency and severity of disaster events are exacerbated by climate change and a rising sea-level. The scale of these changes puts a heavy strain on local communities, many of which lack sufficient capacity to respond. But as Thomas White (this issue) argues, capacity should not merely be understood in terms of technical or scientific expertise. As White demonstrates, churches' capacities in responding to disasters, climate change, and an evidently uncertain future should not be underestimated. ${ }^{17}$

Another dynamic and changeable factor shaping Pacific development concerns the roles played by large development donors. Traditionally, development donors have sought to avoid direct working relations with religious institutions in the Pacific (Cassells, this issue; Clarke, this issue). One remarkable recent experiment in delivering aid has been the Australian Aid Programme's Church Partnership Programme (CPP) in Papua New Guinea. Launched in 2006, the CPP was positioned as an alternative mechanism to enable support for more than state-run health and education services alone. The CPP channels substantial funding through Australian NGOs, all of which are aligned with specific denominations in Papua New Guinea. The provision of development funding through church institutions recognises that, in Papua New Guinea as elsewhere in the Pacific, church institutions remain among the core service providers in these areas (Anderson 2012; 2015; Clarke 2011). Building upon the success of this model, the CPP has also been rolled out in Vanuatu (Clarke, this issue).

One question raised by extensive forms of engagement such as the CPP, and this applies to the many other kinds of partnerships that NGOs have made with churches and Christian community organisations around the region, is the extent to which Christianity is being reconfigured by its involvement in development. Evidence from elsewhere suggests that Christianity may indeed be reshaped through such engagements through the inclusion of new logics, rationales, accountability structures, professional discourses, and authority structures - along with the creation of new languages of agency and temporality, and new institutional forms. ${ }^{18}$ The extent to which such processes have occurred, and continue, in the Pacific remains to be tested but is clearly a question of outstanding significance. 
The goal of this special issue is to open further conversations about the dynamic interactions between Christianity and development in the Pacific. To conclude our introduction, and in conversation with the articles that follow, we want to propose three particular areas that, we believe, will prove especially productive as future lines of research inquiry. These themes are not disciplinary specific, but rather cross over a range of fields.

First, we anticipate new research on Pacific theologies of development. This may take the form of theologising and confessional discourse, and in so doing build upon the vibrant theological scholarship which is already being produced in the region. But this is also an area that deserves much more sustained attention from historians, anthropologists, and others. A thoroughgoing interdisciplinary conversation has opened up over the past few years between anthropology, theology, and history. ${ }^{19}$ While this conversation is properly conceived as broad-ranging, there is particular value in debate and exchange over questions of humanity, charity, progress, sustainability, and the economics of wealth creation and distribution. In different ways, each of the articles in this special issue point to the importance of a nuanced appreciation for the importance of Pacific theologies. Collectively, they make it clear that analysis of development stands to benefit from drawing on differing visions and engaging in robust debate across these differences. Engagement with theology should not be constrained to scholarly discourse, but attention should also be given to vernacular theologies as they are lived and enacted across the Pacific.

Second, we need a much better understanding of the ways in which institutions relate to each other in the Pacific over questions of religion and development. At stake here are not only the myriad institutions that form the many different denominations of the Pacific; nor only the para-church, umbrella bodies, community-based organisations, and service organisations that have proliferated over the past few decades. Rather we are thinking of wider frameworks for examining the state, foreign development agencies, multilateral organisations, and NGOs. This will necessarily involve an analysis not only of engagement and exchange, but also of practices of aversion, diversion, and antagonism. Rigorous examination of the ways in which development institutions of all kinds engage and negotiate with religious actors will help establish a better understanding of how development is carried out in the Pacific. Analysis of institutions will include the ways in which religion-development interactions have resulted in the reconfiguration of both. 
Third, and finally, we look forward to new scholarship that takes seriously the materialities of both religion and development, as well as the ways these dynamic interactions play out within the particularities of Pacific geography. An analysis of materiality must take into account Pacific conceptualisations of both the land and the ocean, as well as corporeality, architecture, relief aid, ritual artefacts, digital representations, infrastructure, and the proliferation of documents that characterises both development and religious bureaucracies. ${ }^{20}$ New attention to the materiality of Christianity will help counteract a still prevalent scholarly misconception that religion primarily concerns beliefs and thereby open new spaces and domains for critical analysis.

\section{ACKNOWLEDGEMENTS}

The papers in this special issue were initially presented as part of the Woven Together? Christianity and Development Between New Zealand and the Pacific conference, which was hosted by Religious Studies at Victoria University of Wellington, 9-10 June, 2016. We are grateful for support from the New Zealand National Commission for Unesco, the New Zealand Aid Programme, and Victoria University of Wellington. Presentations delivered at this conference were valuable in shaping and clarifying our thinking in this paper, and we are grateful to all the participants. We are also grateful for the helpful comments of two anonymous reviewers.

\section{NOTES}

1 Philip Fountain is an anthropologist and Senior Lecturer in Religious Studies at Victoria University of Wellington. He has published extensively on the intersections of religion and development. He was previously a Senior Research Fellow at the Asia Research Institute, National University of Singapore.

Email: philip.fountain@vuw.ac.nz

2 Geoffrey Troughton is a Senior Lecturer in Religious Studies at Victoria University of Wellington. His research focuses on religion in New Zealand society and history. He has written extensively on Christianity in New Zealand and the Pacific region, including, most recently, publications on Christian peace activism and nineteenth-century mission.

Email: geoff.troughton@vuw.ac.nz

3 This data is from the Pew Research Centre (2010): http://www.pewforum. org/2011/12/19/table-christian-population-as-percentages-of-total-populationby-country/ (accessed 6 September 2018). See also relevant chapters in Bouma 
and colleagues (2010). The major exception to this general picture is Fiji, which has a significantly lower percentage of the population claiming to be Christian. A 2007 census reported that 64.4 per cent of Fiji's population is Christian, 27.9 per cent were Hindu, and 6.3 per cent were Muslim. Almost all those affiliated with Hinduism and Islam are Indian Fijians (Bouma et al. 2010, 136).

4 See also John Barker's $(1992,144)$ critique of the ways in which Christianity was seen by anthropologists working in Melanesia as 'spurious, not capable of supporting ethnography'.

5 In addition to Robbins' own seminal work, see also, for example: Handman (2015), McDougall (2016), Miyazaki (2004), Ryle (2010), Scott (2007), and Tomlinson (2009; 2014). Barker's (1990; 1992) important work predates this more recent literature.

6 The Pacific does not loom large in the broader field of the anthropology of development.

7 The life and thinking of leading Kanak independence activist Jean-Marie Tjibaou is particularly illuminating on issues of decolonisation. Initially trained as a Catholic priest, Tjibaou left the priesthood in order to help lead the New Caledonian independence movement. His work engaged extensively with questions of political independence (Waddell 2008).

8 Halapua is a Tongan theologian and former Anglican Bishop of Polynesia and Archbishop and Primate in the Anglican Church of Aotearoa, New Zealand and Polynesia. On Pacific eco-theology see also Leslie Boseto's (1985) meditation on themes of the environment and community.

9 Among many publications relevant to this theme see particularly A Report about Captivity, Liberation and Total Human Development (1977), Women in Development: Report of First PCC Women's Consultation (1979), Island of Hope: A Pacific Alternative to Economic Globalisation (2001), and the Moana Declaration (2009). The Melanesian Institute, located in Goroka, Papua New Guinea, has also produced a prodigious and insightful flow of publications around development issues through their journals Point and Catalyst. See, for example: O’Brien (1979a; 1979b), Fugmann (1986), Spingler (2009), and Schwarz (2011).

10 Within this extensive scholarship see, for example: Meleisea (1987), Lātūkefu (1974), Delbos (1985), Minol and colleagues (2014), Close-Barry (2015), Underwood (2000), and Garrett (1982; 1992; 1997). 
11 See, for example, Uriam (1999), Breward (2001), Ernst (1994, 2006), Forman (1982), and Munro and Thornley (1996).

12 For valuable overviews of this literature, see: Jones and Juul Petersen (2011), Fountain (2013), Fountain and Feener (2017), and Fountain and Juul Petersen (2018).

13 See also Abruzzo (2011), Barnett (2011), Ekbladh (2011), Davies (2013), Stamatov (2013), Fountain (2015), and Curtis (2018). There are, of course, other developments, including those that do not originate solely or even primarily in the West. Moreover, 'Western' developments did not originate autonomously, but rather along transnational and colonial networks, pathways, and 'contact zones' (cf. Pratt 1991). Nevertheless, 'Western development' is clearly implicated in many of the development patterns and models that have been translated and implemented around the world, including in the Pacific.

14 Three important edited volumes by Gerrie ter Haar (2011), Matthew Clarke (2013), and Emma Tomalin (2015) can, taken together, be seen as marking the emergence of the field of religion and development. Despite all three having a global horizon, all gave the Pacific little attention. Although it is structured along regional lines, Tomalin's (2015) volume does not have a section on the Pacific and nor does it include an entry for the Pacific in the index. Ter Haar's (2011) volume contains no significant discussion of the Pacific. Clarke's (2013) Handbook of Research on Religion and Development does better, but nevertheless only one chapter in this volume focuses specifically on a Pacific society.

15 Against this line of argument, Mennonite anthropologist Elmer Miller (1970) argues that Protestant missionaries in South America were the inadvertent conduits of secularisation into indigenous communities. The relevance for this argument in the Pacific context has yet to be examined.

16 Niue and the Cook Islands had been under New Zealand rule since 1901, but military presence in Western Samoa from 1914, and then as a mandated territory from 1919, marked a significant escalation in New Zealand's colonial presence in the Pacific (Salesa 2009).

17 On church responses to disasters in the Pacific, see also Fountain and colleagues (2004) and Cox and colleagues (2018).

18 On the question of how religion is being reconfigured in the age of development, see particularly Feener and Fountain (2018b). 
19 For introductions to these themes, see: Fountain and Lau (2013), Fountain (2013b), Fountain and colleagues (2018), Mathews and Tomlinson (2018), and Lemons (2018).

20 On 'sacred spaces' and development see Clarke and Halafoff (2017). On the need for research that attends to the thingness of both development and religion, see Fountain (2014). For valuable analyses of the materiality of Christianity in the Pacific, see Hermkens (2014) and Jolly (2014).

\section{REFERENCES}

Abruzzo, Margaret. 2011. Polemical Pain: Slavery, Cruelty, and the Rise of Humanitarianism. New Studies in American Intellectual and Cultural History. Baltimore: Johns Hopkins University Press.

Allen, Jamie. 2018. 'Taranaki, Coventry and the Paths of Peace and Reconciliation'. In Pursuing Peace in Godzone: Christianity and the Peace Tradition in New Zealand, edited by Geoffrey Troughton and Philip Fountain, 100-114. Wellington: Victoria University Press.

Anderson, Jane. 2012. "Life in All Its Fullness": Translating Gender in the Papua New Guinea Church Partnership Program'. ssgm Discussion Paper 2012/7. Canberra: Australian National University. https://openresearch-repository. anu.edu.au/bitstream/1885/9848/1/Anderson_LifeFullness2012.pdf

- 2015. 'Struggling With “This Gender Relations Thing” in the Papua New Guinea Church Partnership Program'. Gender, Place and Culture 22 (10):1357-1373.

Armstrong, George. 2018. 'The Peace Squadron Revisited'. In Pursuing Peace in Godzone: Christianity and the Peace Tradition in New Zealand, edited by Geoffrey Troughton and Philip Fountain, 56-72. Wellington: Victoria University Press.

Atia, Mona. 2013. Building a House in Heaven. Pious Neoliberalism and Islamic Charity in Egypt. Minneapolis: University of Minnesota Press.

Barker, John, ed. 1990. Christianity in Oceania: Ethnographic Perspectives. As AO Monograph No. 12. Lanham: University Press of America.

- 1992. 'Christianity in Western Melanesian Ethnography'. In History and Tradition in Melanesian Anthropology, edited by James Carrier, 144-173. Berkeley: University of California Press. 
Barnett, Michael. 2011. Empire of Humanity: A History of Humanitarianism. Ithaca: Cornell University Press.

Benthall, Jonathan, and Jerome Bellion-Jourdan. 2009. The Charitable Crescent: Politics of Aid in the Muslim World. London: I.B. Tauris.

Bertram, Geoff. 2006. 'Introduction: The MIRAв Model in the Twenty-first Century'. Asia Pacific Viewpoint 47 (1):1-13.

Bolotta, Giuseppe, Philip Fountain, and R. Michael Feener, eds. Forthcoming. Political Theologies and Development in Asia: Transcendence, Sacrifice and Aspiration.

Bornstein, Erica. 2005. The Spirit of Development: Protestant NGOs, Morality, and Economics in Zimbabwe. Stanford, CA: Stanford University Press.

- 2012. Disquieting Gifts: Humanitarianism in New Delhi. Stanford, CA: Stanford University Press.

Boseto, Leslie. 1985. 'Environment and Community in Melanesia'. Melanesian Journal of Theology 1:166-173.

Bouma, Gary D., Rod Ling, and Douglas Pratt. 2010. Religious Diversity in Southeast Asia and the Pacific: National Case Studies. Dordrecht: Springer.

Breward, Ian. 2001. A History of the Churches in Australasia. Oxford History of the Christian Church. Oxford: Oxford University Press.

Cammett, Melani. 2014. Compassionate Communalism: Welfare and Sectarianism in Lebanon. Ithaca, NY: Cornell University Press.

Clarke, Matthew. 2011. 'Innovative Delivery Mechanisms for Increased Aid Budgets: Lessons From a New Australian Aid Partnership. Working Paper // World Institute for Development Economics Research 73. Helsinki: United Nations University. https://www.econstor.eu/bitstream/10419/54164/1/672985519.pdf

- 2012. 'God i givim ples ya long yumi (God has given us this land): The Role of the Church in Building Pacific Nations'. In Mission and Development: God's Work or Good Works?, edited by Matthew Clarke, 67-82. New York: Continuum. 
- ed. 2013. Handbook of Research on Religion and Development. Cheltenham: Edward Elgar.

Clarke, Matthew, and Anna Halafoff. 2017. Religion and Development in the AsiaPacific: Sacred Places as Development Spaces. Abingdon: Routledge.

Close-Barry, Kirstie. 2015. A Mission Divided: Race, Culture and Colonialism in Fijis Methodist Mission. Canberra: ANu Press.

Cox, John, Glen Finau, Romitesh Kant, Jope Tarai, and Jason Titifanue. 2018. 'Disaster, Divine Judgement, and Original Sin: Christian Interpretations of Tropical Cyclone Winston and Climate Change in Fiji. The Contemporary Pacific 30 (2):380-410.

Curtis, Heather. 2018. Holy Humanitarians: American Evangelicals and Global Aid. Cambridge: Harvard University Press.

Davidson, Joanna. 2016. Sacred Rice: An Ethnography of Identity, Environment, and Development in Rural West Africa. Oxford: Oxford University Press.

Davies, Thomas. 2013. NGOs: A New History of Transnational Civil Society. London: Hurst \& Company.

Delbos, George. 1985. The Mustard Seed: From a French Mission to a Papuan Church, 1885-1985. Port Moresby: Institute of Papua New Guinea Studies.

Ekbladh, David. 2011. The Great American Mission: Modernization and the Construction of an American World Order. Princeton: Princeton University Press.

Ernst, Manfred, ed. 1994. Winds of Change: Rapidly Growing Religious Groups in the Pacific Islands. Suva: Pacific Conference of Churches.

-2006. Globalization and the Re-shaping of Christianity in the Pacific Islands. Suva: The Pacific Theological College.

Fassin, Didier. 2011. Humanitarian Reason: A Moral History of the Present, translated by Rachel Gomme. Berkeley: University of California Press.

Feener, R. Michael. 2013. Sharia and Social Engineering: The Implementation of Islamic Law in Contemporary Aceh. Oxford: Oxford University Press. 
Feener, R. Michael, and Philip Fountain. 2018a. 'Religion and NGOs: Understanding New Global Configurations of Humanitarian, Development, and "Faithbased” Institutions'. Oxford Department for International Development (ODID) Blog, 21 January 2018. Accessed 12 August 2018 from http://www.qeh. ox.ac.uk/blog/religion-and-ngos-understanding-new-global-configurationshumanitarian-development-and-\%E2\%80\%98faith

- 2018b. 'Religion in the Age of Development'. Religions 9 (382):1-23.

Feener, R. Michael, Philip Fountain, and Robin Bush. 2015. 'Outlook: Research on Religion and Development'. In Religion and the Politics of Development, edited by Philip Fountain, Robin Bush, and R. Michael Feener, 243-245. Basingstoke: Palgrave Macmillan.

Feener, R. Michael, and Catherine Scheer. 2018. 'Development's Missions.' In The Mission of Development: Religion and Techno-Politics in Asia, edited by Scheer, Catherine, Philip Fountain, and R. Michael Feener, 1-27. Leiden: Brill.

Fiddian-Qasmiyeh, Elena. 2014. The Ideal Refugees: Islam, Gender, and the Sahrawi Politics of Survival. Syracuse, NY: Syracuse University Press.

Forman, Charles. 1982. Island Churches of the South Pacific: Emergence in the Twentieth Century. New York: Orbis.

- 2005. 'Finding Our Own Voice: The Reinterpreting of Christianity by Oceanian Theologians'. International Bulletin of Missionary Research 29 (3):115122.

Fountain, Philip. 2011. 'Translating Service: An Ethnography of the Mennonite Central Committee. PhD thesis, Australian National University.

- 2013a.'The Myth of Religious NGOs: Development Studies and the Return of Religion'. International Development Policy: Religion and Development 4:9-30.

- 2013b. 'Toward a Post-Secular Anthropology'. The Australian Journal of Anthropology 24(3):310-328.

- 2014. 'Development Things: A Case of Canned Meat'. Sites: A Journal of Social Anthropology and Cultural Studies 11 (1):39-73. 
- 2015. 'Proselytizing Development'. In The Routledge Handbook of Religions and Global Development, edited by Emma Tomalin, 80-97. London: Routledge.

Fountain, Philip, Robin Bush, and R. Michael Feener, eds. 2015. Religion and the Politics of Development. Basingstoke: Palgrave Macmillan.

Fountain, Philip, and R. Michael Feener. 2017. 'Navigating a World of Religious NGOs: Ethnography, Abstraction, and Views of the Horizon'. Geography Compass 11 (10):1-11.

Fountain, Philip, Douglas Hynd, and Tobias Tan. 2018. 'Theology, Anthropology, and the Invocation to be Otherwise'. St Mark's Review 244:9-20.

Fountain, Philip, and Marie Juul Petersen. 2018. 'Religion and NGOs: Instrumentalisation and its Discontents. In Handbook of Research on NGOs, edited by Aynsley Kellow and Hannah Murphy-Gregory, 404-432. Cheltenham: Edward Elgar.

Fountain, Philip, Sara Kindon, and Warwick Murray. 2004. 'Christianity, Calamity, and Culture: The Involvement of Christian Churches in the 1998 Aitape Tsunami Disaster Relief'. The Contemporary Pacific 16 (2):321-355.

Fountain, Philip, and Sin Wen Lau. 2013. 'Anthropological Theologies: Engagements and Encounters'. The Australian Journal of Anthropology 24 (3):227-234.

Freeman, Dena, ed. 2012. Pentecostalism and Development: Churches, NGOs and Social Change in Africa. Basingstoke: Palgrave Macmillan.

Fugmann, Gernot, ed. 1986. Ethics and Development in Papua New Guinea. Special Issue: Point 9.

Gallagher, Nancy. 2007. Quakers in the Israeli-Palestinian Conflict: The Dilemmas of NGO Humanitarian Activism. Cairo and New York: The American University in Cairo Press.

Gardner, Helen. 2013. 'Praying for Independence: The Presbyterian Church in the Decolonisation of Vanuatu'. Journal of Pacific History 48 (2):122-143.

Garrett, John. 1982. To Live among the Stars: Christian Origins in Oceania. Geneva and Suva: World Council of Churches and Institute of Pacific Studies, Uni- 
versity of the South Pacific

-1992. Footsteps in the Sea: Christianity in Oceania to World War II. Suva and Geneva: Institute of Pacific Studies, University of the South Pacific in association with the World Council of Churches.

- 1997. Where Nets Were Cast: Christianity in Oceania since World War II. Suva and Geneva: Institute of Pacific Studies, University of the South Pacific in association with the World Council of Churches.

Gifford, Paul. 2016. Christianity, Development and Modernity in Africa. Oxford and New York: Oxford University Press.

Halapua, Winston. 2010. 'Theomoana: Toward an Oceanic Theology’. In Oceania and Indigenous Theologies, edited by Dennis Gira, Diego Irarrázaval, and Elaine Wainwright. 23-33. London: sсм Press.

Handman, Courtney. 2015. Critical Christianity: Translation and Denominational Conflict in Papua New Guinea. Oakland: University of California Press.

Hassall, Graham. 1990. 'Religion and Nation-State Formation in Melanesia, 1945 to Independence'. PhD thesis, Australian National University.

Hau’ofa, Epeli. 1993. 'Our Sea of Islands'. In A New Oceania: Rediscovering Our Sea of Islands, edited by Eric Waddell, Vijay Naidu, and Epeli Hau'ofa, 2-16. Suva: School of Social and Economic Development, University of the South Pacific.

Hefferan, Tara. 2007. Twinning Faith and Development: Catholic Parish Partnering in the US and Haiti. Bloomfield, CT: Kumarian Press.

Hefferan, Tara, Julie Adkins, and Laurie Occhipinti, eds. 2009. Bridging the Gaps: Faith-based Organizations, Neoliberalism, and Development in Latin America and the Caribbean. Lanham, MD: Lexington Books.

Hermkens, Anna-Karina. 2014. 'The Materiality of Missionisation in Collingwood Bay, Papua New Guinea' In Divine Domesticities: Christian Paradoxes in Asia and the Pacific edited by Hyaeweol Choi and Margaret Jolly, 397-427. Canberra: ANU Press.

Huang, Julia. 2009. Charisma and Compassion: Cheng Yen and the Buddhist Tzu Chi Movement. Cambridge, Mass.: Harvard University Press. 
Ilo, Stan Chu. 2011. The Church and Development in Africa: Aid and Development from the Perspective of Catholic Social Teaching. Eugene, OR: Wipf and Stock.

Jones, Ben, and Marie Juul Petersen. 2011. 'Instrumental, Narrow, Normative? Reviewing Recent Work on Religion and Development'. Third World Quarterly 32 (7):1291-1306.

Jolly, Margaret. 2014. 'A Saturated History of Christianity and Cloth in Oceania'. In Divine Domesticities: Christian Paradoxes in Asia and the Pacific edited by Hyaeweol Choi and Margaret Jolly, 429-454. Canberra: ANU Press.

Kawanami, Hiroko, and Geoffrey Samuel. 2013. Buddhism, International Relief Work, and Civil Society. Basingstoke: Palgrave Macmillan.

Lātūkefu, Sione. 1974. Church and State in Tonga: The Wesleyan Methodist Missionaries and Political Development, 1822-1875. Canberra: Australian National University Press.

Lemons, J. Derrick, ed. 2018. Theologically Engaged Anthropology. Oxford: Oxford University Press.

Li, Tania Murray. 2007. The Will to Improve: Governmentality, Development, and the Practice of Politics. Durham, NC: Duke University Press.

Magowan, Fiona, and Carolyn Schwarz, eds. 2016. Christianity, Conflict, and Renewal in Australia and the Pacific. Leiden: Brill.

Matheson, Peter. 2018. 'Revolution at the Kitchen Tables: Churches and the 1980s Peace Movement'. In Pursuing Peace in Godzone: Christianity and the Peace Tradition in New Zealand, edited by Geoffrey Troughton and Philip Fountain, 73-85. Wellington: Victoria University Press.

Mathews, Jeanette, and Matt Tomlinson. 2018. 'Introduction: Conversations Between Theology, Anthropology, and History'. St Mark's Review 244 (2):1-8.

McDougall, Debra. 2016. Engaging with Strangers: Love and Violence in the Rural Solomon Islands. As ao Studies in Pacific Anthropology Vol. 6. New York: Berghahn Books.

Minol, Bernard, Dorcas Pwahau, Francis Kolpai. 2014. A Brief History of N’Dranou Local Church. Port Moresby: UPNG Press. 
Mitchell, Timothy. 2002. Rule of Experts: Egypt, Techno-Politics, Modernity. Berkeley: University of California Press.

Miyazaki, Hirokazu. 2004. The Method of Hope: Anthropology, Philosophy, and Fijian Knowledge. Stanford: Stanford University Press.

Meleisea, Malama. 1987. The Making of Modern Samoa: Traditional Authority and Colonial Administration in the History of Western Samoa. Suva: University of the South Pacific Press.

Miller, Elmer. 1970. 'The Christian Missionary, Agent of Secularization'. Anthropological Quarterly 43 (1):14-22.

Munro, Doug, and Andrew Thornley, eds. 1996. The Covenant Makers: Islander Missionaries in the Pacific. Suva: Pacific Theological College.

O’Brien, Helen, ed. 1979a. Religion and Development (1). Special Issue: Point 1.

-1979b. Religion and Development (2). Special Issue: Point 2.

Occhipinti, Laurie. A. 2005. Acting on Faith: Religious Development Organizations in Northwestern Argentina. Lanham, MD: Lexington Books.

Pacific Council of Churches. 1977. A Report about Captivity, Liberation and Total Human Development. Suva: Pacific Council of Churches.

- 1979. Women in Development: Report of First PCC Women's Consultation. Suva: Lotu Pasifika Productions.

- 2001. Island of Hope: A Pacific Alternative to Economic Globalisation. Report of the Churches' Conference on Economic Globalisation. Mocambo Hotel, Nadi, Fiji.

- 2009. 'Moana Declaration'. Nadi, Fiji,

Porter, Andrew. 2004. Religion Versus Empire? British Protestant Missionaries and Overseas Expansion, 1700-1914. Manchester: Manchester University Press.

Pratt, Mary Louise. 1991. 'Arts of the Contact Zone'. Profession 91:33-40.

Riles, Annelise. 200o. The Network Inside Out. Ann Arbor: University of Michigan Press. 
Rist, Gilbert. 2014. The History of Development: From Western Origins to Global Faith. 4th ed. London: Zed Books.

Robbins, Joel. 2003. 'What is a Christian? Notes Toward an Anthropology of Christianity'. Religion 33 (3):191-199.

-2004. Becoming Sinners: Christianity and Moral Torment in a Papua New Guinea Society. Berkeley: University of California Press.

- 2007. 'Continuity Thinking and the Problem of Christian Culture: Belief, Time, and the Anthropology of Christianity'. Current Anthropology $48(1): 5-38$.

Rudnyckyj, Daromir. 2010. Spiritual Economies: Islam, Globalization, and the Afterlife of Development. Ithaca, NY: Cornell University Press.

Ryle, Jacqueline. 2010. My God, My Land: Interwoven Paths of Christianity and Tradition in Fiji. Anthropology and Cultural History in Asia and the IndoPacific. Farnham: Ashgate.

Salesa, Damon. 2009. 'New Zealand's Pacific'. In The New Oxford History of New Zealand, edited by Giselle Byrnes, 149-172. Auckland: Oxford University Press.

Scheer, Catherine, Philip Fountain, and R. Michael Feener, eds. 2018. The Mission of Development: Religion and Technopolitics in Asia. Leiden: Brill.

Scherz, China. 2014. Having People, Having Heart: Charity, Sustainable Development, and Problems of Dependence in Central Uganda. Chicago: University of Chicago Press.

Schwarz, Nick, ed. 2011. Blessed are the Virtuous? Evangelicals and Pentecostals in Papua New Guinea Speak about HIV/AIDS. Special Issue: Point 35.

Scott, Michael W. 2007. The Severed Snake: Matrilineages, Making Place, and a Melanesian Christianity in Southeast Solomon Islands. Durham, NC: Carolina Academic Press.

Sissons, Jeffrey. 2014. The Pacific Iconoclasm: Religious Revolution and the Seasonality of Power. As Ao Studies in Pacific Anthropology, v. 5. New York: Berghahn Books. 
Siwatibau, Suliana, and David Williams. 1982. A Call to a New Exodus: An AntiNuclear Primer for Pacific People. Suva: Pacific Council of Churches.

Smith, James H. 2008. Bewitching Development: Witchcraft and Reinvention of Development in Neoliberal Kenya. Chicago: University of Chicago Press.

Spingler, Hermann, ed. 2009. AIDS, Belief and Culture in Papua New Guinea. Special Issue: Catalyst: Social Pastoral Journal for Melanesia 39 (2).

Stamatov, Peter. 2013. The Origins of Global Humanitarianism: Religion, Empires, and Advocacy. New York: Cambridge University Press.

Stanley, Brian. 1990. The Bible and the Flag: Protestant Missions and British Imperialism in the Nineteenth and Twentieth Centuries. Leicester: Apollos.

Teaiwa, Teresia K. 1994. 'bikinis and other s/pacific n/oceans'. The Contemporary Pacific 6 (1):87-109.

Ter Haar, Gerrie, ed. 2011. Religion and Development: Ways of Transforming the World. New York: Columbia University Press.

Tomalin, Emma, ed. 2015. The Routledge Handbook of Religions and Global Development. London: Routledge.

Tomlinson, Matt. 2009. In God's Image: The Metaculture of Fijian Christianity. Berkeley: University of California Press.

- 2014. Ritual Textuality: Pattern and Motion in Performance. New York: Oxford University Press.

- Forthcoming. God is Samoan: Dialogues between Culture and Theology in the Pacific. Honolulu: University of Hawaii Press.

Tomlinson, Matt, and Debra McDougall, eds. 2012. Christian Politics in Oceania. As Ao Studies in Pacific Anthropology Vol. 2. New York: Berghahn Books.

Troughton, Geoffrey, ed. 2017. Saints and Stirrers: Christianity, Conflict and Peacemaking in New Zealand, 1814-1945. Wellington: Victoria University Press.

Troughton, Geoffrey, and Philip Fountain. 2018. 'Pursuing Peace in Godzone'. In Pursuing Peace in Godzone: Christianity and the Peace Tradition in New Zea- 
land, edited by Geoffrey Troughton and Philip Fountain, 17-29. Wellington: Victoria University Press.

Underwood, Grant, ed. 20oo. Voyages of Faith: Explorations in Mormon Pacific History. Provo: Brigham Young University Press.

Watanabe, Chika. 2019. Becoming One: Religion, Development, and Environmentalism in a Japanese NGO in Myanmar. Honolulu: University of Hawaii Press.

Uriam, Kambati. 1999. 'Theology and Practice in the Islands: Christianity and Island Communities in the New Pacific, 1947-1997'. PhD thesis, Australian National University.

van der Veer, Peter, ed. 1996. Conversion to Modernities: The Globalization of Christianity. New York: Routledge.

- 2013. The Modern Spirit of Asia: The Spiritual and the Secular in China and India. Princeton: Princeton University Press.

Waddell, Eric. 20o8. Jean-Marie Tjibaou, Kanak Witness to the World: An Intellectual Biography. Honolulu: University of Hawai'i Press.

Weir, Christine H. 2012. 'Ending Nuclear Testing in the Pacific: Bishop Bryce and the Pacific Conference of Churches'. Unpublished conference paper. Pacific History Association Conference, Wellington, New Zealand. http://repository. usp.ac.fj/5658/

Weller, Robert, C. Julia Huang, Keping Wu, and Lizhu Fan. 2017. Religion and Charity: The Social Life of Goodness in Chinese Societies. Cambridge: Cambridge University Press. 